\title{
Analysis of the causes and recommendations on elimination of biological damage of structures during the repair and reconstruction of the State Biological Museum in Moscow.
}

\author{
Victor Kamskov ${ }^{1, *}$ \\ ${ }^{1}$ Moscow state university of civil engineering, Yaroslavskoye shosse, 26, Moscow, Russia, 129337
}

\begin{abstract}
The article presents the results of mycological research on buildings of the State Biological Museum located in Moscow. The problems have been considered as for a complex of buildings of the State Biological Museum built in the late nineteenth century which, to the present time, has been operated almost in its original form. Over time, the building maintenance conditions have worsened, in particular because of construction of high-rise buildings in the immediate vicinity of the museum, as well as construction of a greenhouse above the underground passage tunnel between buildings 1 and 2. Over the years, the temperature gradients, high humidity, wear and damage of wall waterproofing and foundations have caused leaks in the underpass tunnel and the biological corrosion of stone, wood and metal structures in indoor exhibition halls. In this connection, part of the survey was to determine the types and size of biological lesions in structures, determination of the causes of biological damage, and the development of measures to eliminate the mycological problems during repair and reconstruction works in the museum.
\end{abstract}

\section{Introduction.}

The main exhibition halls of the museum located in the building (building 1) designed by the architect A.E.Erichson in 1898. Until the present time, basements and premises of the 1st and 2nd floors have been used. In the building (Building 2), designed by the architect B.V.Freudenberg, museum administration, research laboratories, restoration workshops, scientific library, shopping service are located. To connect the buildings 1 and 2 the architect A.E.Erichson designed and built an underground passage shown in Fig. 1. Later on, above the tunnel a greenhouse was built for year-round operation with electric lighting, hot and cold water supply, sewerage. The tunnel is equipped with manholes, which are destined for lighting the tunnel interior space with natural light. Over the years, the temperature gradients, high humidity, worn waterproofing caused leakage through the tunnel body. Mould colonies appeared (Figure 2), which caused the biological corrosion of stone materials in the tunnel. $(1,2,8)$

\footnotetext{
* Corresponding author: kamskov@mail.bg
} 


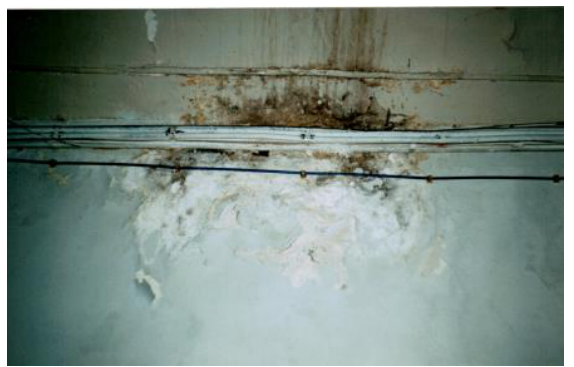

Fig. 1. Mould colony in the underground passage.

The biological corrosion mostly damaged internal and external walls of buildings 1 and 2 , as well as wooden structures of attic rooms, and metal structural components of cellars. The aim of research was determining type and size of biological damage and making recommendations for its elimination in anticipation of the reconstruction works in the museum. (7)

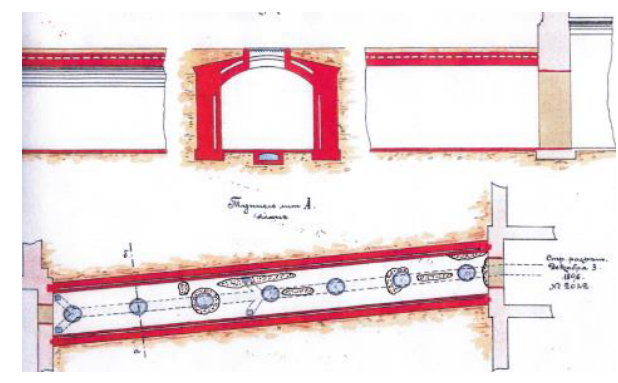

Fig. 2. Location of mould colonies in the underground passage between the buildings 1 and 2 .

\section{Problems.}

The aim of this research was to determine the real technical condition of the buildings of the State Biological Museum in terms of biological and chemical corrosion and to define "treatment" methods of building structures for restoration and reconstruction works. In this connection, for research the most affected buildings 1 (1898) and 2 (1892-93) and the underpass between the buildings were selected. $(3,4,5,6)$.

Building 1 has a basement floor and two underground floors and an attic room located in the space. A general view of the structure 1 and a greenhouse on an underground passage between buildings 1 and 2 is presented in Figure 3.

a)

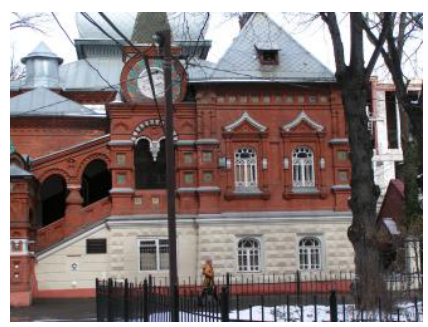

b)

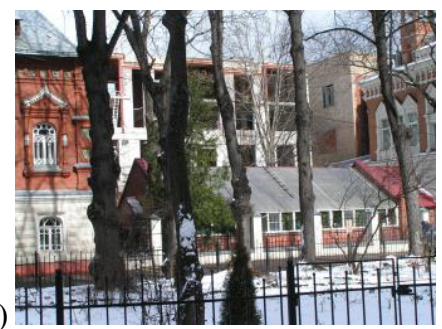

Fig. 3. General view of the building 1 and the greenhouse above the underground passage between buildings 1 and $2\{a)$ and b) $\}$. 
A mycological research showed that moulds destroy plasters and concrete surface, on the one hand, and, on the other, adversely affect the health of the personnel permanently working in these areas. Various kind of corrosive media (natural and industrial) damage $15 \%$ to $75 \%$ of building structures of buildings. In addition to inorganic corrosive environments, significant devastating impact on building materials and construction of buildings and structures is exercised by animals and plant macro- and microorganisms and their derivatives, i.e. by biogenic aggressive media.

The bio corrosion can be divided in:

- impact of bacteria;

- impact of moulds;

- impact of moss, lichen, and lower algae.

Chemical destruction of stone is the result of the action of acid products on it, produced during the growth of microorganisms of inorganic and organic acids and carbon dioxide. The most severe destruction of stone materials is produced by nitric and sulfuric acid, microbial oxidation products of gases, present in the atmosphere.

Nitrate bacteria oxidizing ammonia to nitrate, convert limestone chemical chalk into soluble nitrate. As a result, in the chemical process, limestone fully loses adhesion and gets converted to powder. This powder is blown by the wind and washed away by water. Silicate rocks are more resistant to the action of nitric acid. However, their destruction is greatly accelerated in the presence of nitrate bacteria. Not less destruction is produced by sulfuric acid from sulfur-oxidizing bacteria. For example, it reacts with calcium hydroxide $\mathrm{Ca}(\mathrm{OH})_{2}$ formed during cement hardening. This gives rise to new compounds - gypsum $\mathrm{CaSO}_{4} \cdot 2 \mathrm{H}_{2} \mathrm{O}$ - which occupies a volume 2 -fold greater than the $\mathrm{Ca}(\mathrm{OH})_{2}$ or calcium hydrosulfoaluminate $\mathrm{AL}_{2} \mathrm{O}_{3} \cdot 3 \mathrm{CaO} \cdot 3 \mathrm{CaSO}_{4} \cdot 32 \mathrm{H}_{2} \mathrm{O}$. The formation of such salts creates internal tensions in concrete and leads to cracking. In the presence of organic compounds on stone materials mainly fungi and heterotrophic bacteria develop. Most of the organic matter is decomposed by them into carbon dioxide and water.

Carbon dioxide plays a big role in the destruction of stone. This process is described by a simple chemical reaction. Calcium carbonate, which is part of limestone and concrete, is converted in presence of carbon dioxide and water to calcium bicarbonate: $\mathrm{CaCO}_{3}+\mathrm{CO}_{2}+$ $\mathrm{H}_{2} \mathrm{O} \rightarrow \mathrm{Ca}\left(\mathrm{HCO}_{3}\right)_{2}$. Assuming that the solubility of $\mathrm{CaCO}_{3}$ equals to $0.031 \mathrm{~g} / 1 \mathrm{dm}^{3}$ of water, solubility of the calcium bicarbonate $\mathrm{Ca}\left(\mathrm{HCO}_{3}\right)_{2}$ is $1.89 \mathrm{~g} / 1 \mathrm{dm}^{3}$ of water and easily washed away with water from a stone. Similarly, although somewhat slower, silicate rocks get destructed. Feldspar and mica, a part of granite, also form water-soluble compounds under the action of carbon dioxide and water.

Organic substances present on the surface and in the structure of stone materials, may be not fully degraded by micro-organisms, so along with the carbon dioxide organic acids are formed. They penetrate the substrate and reduce the $\mathrm{pH}$ in the growth zone. However, in terms of biodegradation of stone, chelating ability of organic acids is more important than acidifying ability since the release of cations from rock minerals by forming water soluble complexes leads to more rapid disruption of the integrity of sandstone, limestone and concrete.

The mechanism of destruction of cement materials by fungi is the following. Fungi throughout their life secrete various mineral and organic acids (acetic, citric, lactic, butyric, formic, malic, etc.) which interact with basic (alkaline) cement stone compounds and destroy it, with turning hydrosilicates and hydroaluminates to non-astringent salts. Cement stone degenerates and loses its construction and technical properties. Fungi, algae, lichens insert destroy stone materials not only chemically, by the action of metabolism products, but also mechanically. 
The biomass growth of microorganisms penetrated into pores and micro cracks, contributes to their expansion. Intermittent wetting and drying lichens, accompanied by a significant change in the cell volume, results in cyclical pressure on walls of cracks and in fatigue failure of stone. The ability of the fungal mycelium to condense on its surface an increased amount of moisture increases the distraction effect of cyclic freezing and thawing of water in stone pores and cracks. There are three main groups of methods of protection of building structures from the destructive action of fungi: performance/preventive, design, and construction/technology methods.

The first group includes surface disinfection methods, regulation of heat and humidity environment mode in premises, and ventilation. Constructive measures include imparting to the structure surfaces the forms in which wetting of structures and accumulation of dust on the surface decreases. Construction/ technology activities include the use of materials resistant to fungi.

Fouling of structures with microscopic fungi, breeding of bacteria in porous construction material creates hygienic problems. Bacteria and fungal spores, substances secreted by bacteria and fungi can cause serious disease in humans, living or working in the affected areas, in particular, the development of allergic and respiratory diseases, as well as pneumonia and liver cirrhosis, especially in children. Some of substances secreted by microorganisms are dangerous toxins. In any case, it is believed that the reason for the seemingly inexplicable people's death, who opened tombs of Egyptian pharaohs, is the socalled yellow mould releasing hazardous substance aflatoxin.

In the buildings constructed in the first half of the 19th century and earlier, as a rule, there is no horizontal waterproofing. Also, when building-up this cultural layer waterproofing ceases to perform its function. This leads to dampen the walls due to capillary moisture suction. This reduces the insulating properties of the walls and their longevity because of destruction of freeze-thaw, salt corrosion and biocorrosion.

From construction physics it is known that an increase in humidity of outer brick walls only by $3 \%$ increases their heat conductivity by $50 \%$. The temperature on the inner wall surface of premises with normal indoor air parameters, that is, at temperature of $18{ }^{\circ} \mathrm{C}$ and humidity of $55 \ldots 60 \%$ - is normally $14 \ldots 16^{\circ} \mathrm{C}$. This temperature corresponds to the standard of thermal acceptability and does not cause the appearance of condensate (at the normal natural ventilation removing excess household moisture). If the wall is waterlogged, the temperature on its surface drops to $+9{ }^{\circ} \mathrm{C}$ and it inevitably results in household condensate and moisture exhaled by people who are in the room. The condensate precipitated is absorbed into the wall, and its heat conductivity is even greater, and so the process is repeated.

Because of capillary suction of moisture at the masonry seams of foundations and walls the construction material is exposed to salt corrosion, which is manifested in the form of leaching or, conversely, salinization of these materials. At the capillary suction of groundwater followed by crystalhydrate addition of water to anhydrous salts of building materials formed such minerals as $\mathrm{CaSO}_{4} \cdot 2 \mathrm{H}_{2} \mathrm{O}$ (plaster), $\mathrm{MgCl}_{2} \cdot 6 \mathrm{H}_{2} \mathrm{O}$ (bischofite), $\mathrm{CaCl}_{2} \cdot 2 \mathrm{H}_{2} \mathrm{O} \cdot \mathrm{MgSO}_{4} \cdot 2 \mathrm{H}_{2} \mathrm{O}$ (kieserite), $\mathrm{MgSO}_{4} \cdot 6 \mathrm{H}_{2} \mathrm{O}$ (hexahydrite), $\mathrm{Na}_{2} \mathrm{CO}_{3} \cdot 10 \mathrm{H}_{2} \mathrm{O}$ (soda), $\mathrm{NaCl} \cdot 2 \mathrm{H}_{2} \mathrm{O}$ ( hydrohalite), $\mathrm{Na}_{2} \mathrm{SO}_{4} \cdot 10 \mathrm{H}_{2} \mathrm{O}$ (mirabilite) are formed.

Upon addition of water by anhydrous salts to form crystalhydrates the volume of the solid phase augments and a tensile stress appears in the material pore walls that reaches the values of $0.21-0.44 \mathrm{MPa}$. Apart of that, the pressure of crystalhydrates is a permanent load, and that reduces the durability of material. Thus, the strength of ceramic bricks comprising crystalhydrates of the above salts is reduced by $30-40 \%$ and the frost resistance of salinized cement concrete is reduced by 2.5 times. Following methods are used for desalting the structures:

electroosmosis; 
- $\quad$ use of sanitizing plasters;

- conversion of salts comprised in materials into insoluble compounds.

Mycological studies of structural elements of the building, for example, of walls, beams, expansion joints, etc. give rise to the development of recommendations for combating molds.

\section{Results}

Visual inspection results as for biocorrosion are demonstrated in the table 1.

Table 1 Visual inspection results as for biocorrosion

\begin{tabular}{|l|l|l|}
\hline Building cellar. & Biocorrosion behaviour & $\begin{array}{l}\text { Place and area of lesion, } \\
\mathrm{m} 2\end{array}$ \\
\hline Work rooms & White mould and green mould & Walls, 12 m2 \\
\hline Work rooms & Green and black mould & Walls , 10 m2 \\
\hline Cellar & Green and black mould & Walls, $20 \mathrm{~m} 2$ \\
\hline
\end{tabular}

The figure 4 shows colonies of mould fungi in their location places.

a)

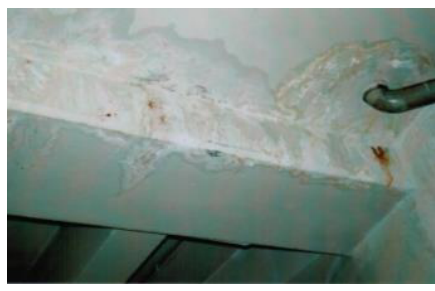

b)

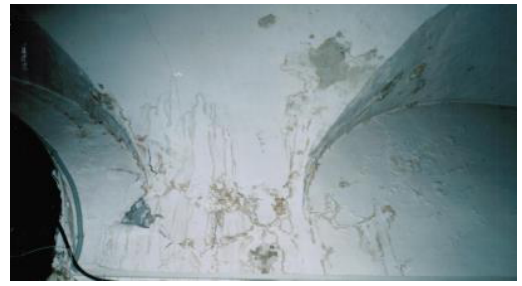

a) on the wall; b) in the vestibule ceiling

Fig. 4. Colonies of mould fungi in their location places of the building 2 .

It was noted earlier that mould fungi show up on the surface of building materials at following conditions: humidity of wall materials approx. $10 \%$; ambient temperature approx. $+15 \ldots 18^{0} \mathrm{C}$.

The development of fungi is facilitated by poor ventilation of premises. These factors shown are observed in the investigated areas.

Analysis of the places of location of fungal lesions (Fig. 4) showed that in the centers of biocorrosion paint and plaster coatings are mostly destroyed. Additional danger of colonies consists in that they are a background for germing of the fungus Serpula Lakrimas, which damages books and other materials.

Microscopic analysis of samples taken in different rooms has shown that in this building there are the following types of fungi: white mould (Penicilium), green mould (Aspergilium), black mould (Cladosporium). Mould colonies develop in the specified order. Note that the plastered surfaces in the building are painted with oil paint, which with time forms shrinkage cracks. Spores colonize the cracks, leading to the formation of white mould colonies, which detach oil paint. Afterwards green mould colonies arise that create a breeding ground for black mould.

Moulds develop at substrate humidity $8 \ldots 10 \%$ and at the temperature above $10 \mathrm{C}$. The humidity material is provided by the absence of cut-off waterproofing and by basement premises conditions as well as by the presence of structural defects, at the inside temperature over $18{ }^{\circ} \mathrm{C}$. Especially intense development of moulds takes place in rooms with high humidity and in unventilated areas. Fig. 5 shows micrographs of plaster solution 
samples with various types of moulds, made by means of the electronic microscope «Camebax» (Japan), 2000 x zoom.

a)

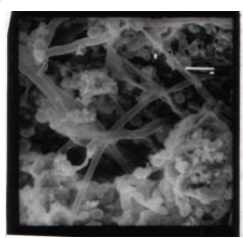

b)

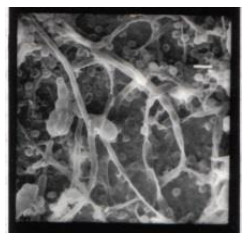

c)

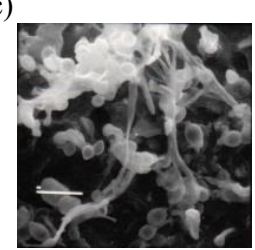

a) white mould; b) green mould, c) black mould

Fig. 5. Dissolved plaster samples with different types of mould.

The data (Fig. 5) prove the development activity of fungi lesions (presence of mycelium, punks). In this case, it is necessary to note the increase in density of their biomass, which in itself is a destructive factor. Note that the biocorrosion mainly affects sand-cement compositions (plaster coverings) because a breeding ground for them is calcium hydroxide $\mathrm{Ca}(\mathrm{OH})_{2}$. In addition, the plaster samples taken demonstrated the lowest durability of soluted cement-sand plaster.

Next, we carried out the study on wooden structures of the building tested using an electron probe microanalyzer. The electron-probe microanalyzer provides X-ray radiation of the sample researched, excited with an electron beam. For the identification of elements contained in the sample and determination of their concentration, the wavelength and intensity of the respective X-ray spectral lines were measured for a certain time, for example, for 100 seconds. For determining the material composition of the material it is necessary to register in the X-ray spectrum of the analyzed line elements in the 1 - A 12 range and compare them with X-ray lines emitted by reference samples of a known composition. Characteristic X-ray emission lines are formed, the lengths of which uniquely characterize a chemical element whose atoms emit these lines.

Putrefaction or decomposition of wood is accompanied by influence of "cytase" enzymes secreted by microorganisms or wood destroying fungi. Cytase as a catalyst, converts a water-insoluble cellulose in insoluble substance - glucose, in the following reaction:

$$
\left(\mathrm{C}_{6} \mathrm{H}_{10} \mathrm{O}_{5}\right) \mathrm{n}+\mathrm{H}_{2} \mathrm{O}+\text { cytase }=\left(\mathrm{C}_{6} \mathrm{H}_{12} \mathrm{O}_{6}\right) \mathrm{n}
$$

Glucose is oxydized by ambient oxygene, with forming carbon dioxide and water. The reaction:

$$
\left(\mathrm{C}_{6} \mathrm{H}_{12} \mathrm{O}_{6}\right) \mathrm{n}+6 \mathrm{O}_{2}=6 \mathrm{CO}_{2}+6 \mathrm{H}_{2} \mathrm{O}
$$

The chemical composition is a determinant of defeat of wood by fungi. At the same time, the sum of oxides fairly accurately characterizes the type of lesion, and iron oxide $\mathrm{Fe}_{2} \mathrm{O}_{3}$ comprised in the chemical composition indicates the presence of a strong oxidant, which is cytase. Mikrofotographing a test sample confirms the chemical analysis.

Threadlike spores with oval heads characterize the "real wood fungus" growing mainly on dead wood, which is the most dangerous of all destroying fungi. The filamentous fungal spores of sap-wood rot found in the wood walls of the building tested are shown in Fig. 6.

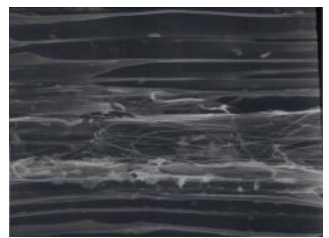

Fig. 6. Threadlike fungi spores of sap-wood rot, found in wooden walls of the building tested. 
Another timber destroyer - "mine fungus" has spores in the form of filamentary chains, pierced with smooth fibers, binding all in a single unit (Figure 7).

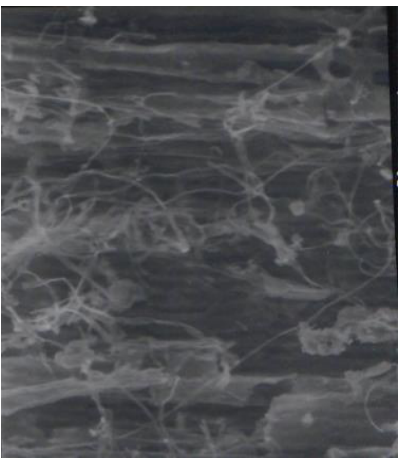

Fig. 7. Thread fungi spores found in wooden walls of the building.

Wood failure occurs as a result of mineralization of pore space with gypsum. It is found that the presence of sulfur oxide is $4.51 \%$ and of calcium oxide $6.44 \%$. These are exactly the components of the formula of gypsum $\mathrm{CaSO}_{4} \times 2 \mathrm{H}_{2} \mathrm{O}$. The concentration of sodium oxide is $0.722 \%$ and chlorine oxide is $0.773 \%$, and that indicates the presence of $\mathrm{NaCl}$ crystals in the wood pores. The growth of salt crystals is accompanied by an increase in their volume and the appearance of internal stresses that reduce the strength of wood structural elements.

The study of metal structures was conducted using X-ray diffraction method. Figure 8 is an X-rayogram of rust, efflorescence scale and the most damaged portions of steel structures that are complex salts containing $\mathrm{NaCl}, \mathrm{Na}_{2} \mathrm{CO}_{3}, \mathrm{MgCO}_{3}$, and the silica gel $\mathrm{Si}(\mathrm{OH})_{4}$. These include such as $\mathrm{Fe}_{2} \mathrm{O}_{3} \mathrm{xCO}_{3} ; \mathrm{Fe}_{2} \mathrm{Si}_{2} \mathrm{O}_{5}(\mathrm{OH})_{4} 2 \mathrm{H}_{2} \mathrm{O} ; \mathrm{Na}_{3} \mathrm{Mg}\left(\mathrm{CO}_{3}\right)_{2} \mathrm{Cl}$.

Chlorides of sodium and magnesium metals in combination with the moisture are steel corrosion process activators. They are adsorbed on the surface of structures, displacing oxygen and causing pitting corrosion of steel.

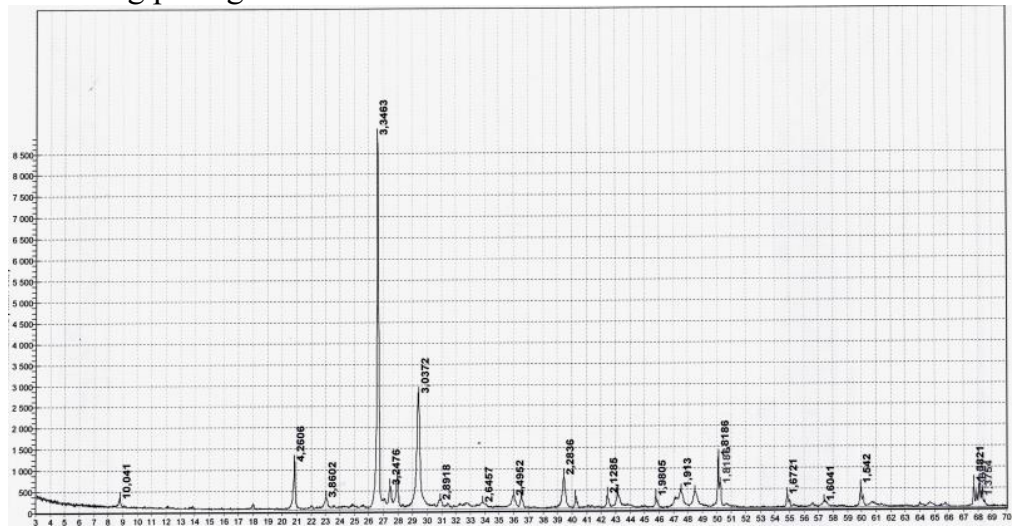

Fig. 8. X-rayogram of the microstructure of the most damaged parts of steel structures.

Sodium carbonate is the product of artificial origin and, accumulating in the pore space, it increases its volume, creating internal stresses.

$\alpha \mathrm{FeO}(\mathrm{OH})$ and $\gamma \mathrm{FeO}(\mathrm{OH})$ - alpha and gamma hydrohematite - the substances having high absorption properties and increasing the initial volume. Thus, neoplasms $\mathrm{Fe}\left(\mathrm{HCO}_{3}\right), \alpha$ 
$\mathrm{FeO}(\mathrm{OH})$ and $\gamma \mathrm{FeO}(\mathrm{OH})$ provoke internal stresses and destroy steel bearing components of the building.

\section{Conclusions and recommendations}

While developing measures to eliminate mould, you must first remove conditions favorable for their development, i.e. surface humidity of wall materials exceeding $10 \%$. Otherwise, the fungicidal treatment of wall materials will be effective for not longer than 2 years.

For fungicidal treatment of premises the approved preparation "Cartocide-Compound" developed by the "NIOPIK" (SRI of dyes and semi-finished products) is recommended. The preparation comprises the following active ingredients: Cartocide, yuglog, permethrin and glisol. Furthermore, all the brand preparations contain acetate buffer and acetic acid to create a certain $\mathrm{pH}$ level and surfactants as well.

All "Cartocide - Compound" brands are to be shaken before use, and then mixed with water in desired ratios, and applied to the object to be protected by any known method (brushing, spraying, impregnating, dipping, soaking, etc.).

All preparation brands due to the surfactants comprised have high wettability, which increases the total penetrating (impregnating) action. The most popular brands are "Cartocide-compound" B-1 and B-1k, used for processing internal wooden, concrete and brick surfaces from staining and destructive fungal and bacterial diseases.

Brand «B-1»-5\% aqueous solubilizate (solution) of Cartocid and Yuglog, prepared of 98\% Cartotsid dry powder or of its $50 \%$ aqueous solution with addition of surfactant and acetate buffer.

Brand «B-1 k» - 30\% aqueous solubilizate of Cartotside and Yuglog, prepared of 98\% Cartotside dry powder or of its $50 \%$ aqueous solution with addition of surfactant and acetate buffer.

\section{References}

1. V.P. Kamskov, V.V. Kozlov, Hydroisolation materials. Nautchnoye izdanie. Moscow, (2014)

2. V.P. Kamskov, V.S. Semionov, I.V. Balandina, A.A. Pakhratdinov, Investigation of Reasons for Presence of Gaseous Products in Concrete of Monolith Ferroconcrete Structures of a School Building in Moscow. Nautchnoye obozrenie, 19, 77-81 (2015)

3. V.P. Kamskov, R.F. Serova, E.A. Stasilovich, Investigation of Reasons of Splitting-off of Concrete from Ferroconcrete Bearing Structures of a Frame Building. Vestnik sovremennoi Nauki, 12-1 (12), 39-43 (2015)

4. V.P. Kamskov, I.V. Balandina, D.Yu. Zemlyanushnov, Research of Reasons of Destruction of Cement/Sand Screed for the Floor and Polymer Coating. Methods of their Repair. Sovremennye tendentsii razvitiya nauki i tekhnologiy, 9-3, 95-99 (2015)

5. A. Grishina, E.V. Korolev, Chemical Composition of Biocide Silicate-based Modifier. Vestnik MGSU, 11, 58-67 (2016)

6. A. Grishina, E.V. Korolev, AIP Conference Proceedings 13. Ser. "Prospects of Fundamental Sciences Development, PFSD-2016: Proceedings of the XIII International Conference of Students and Young Scientists, 20-26 (2016)

7. A. Grishina, E.V. Korolev, Strength of Gypsum Stone comprising a Biocide Modifier// Evraziyskiy coyuz uchyonykh. 30-2, 21-24 (2016) 